\title{
TYPE STUDIES ON FRULLANIA SUBGENUS METEORIOPSIS (MARCHANTIOPHYTA). VII. ON $F$. ANGULATA MITT. AND F. LONGISTIPULA STEPH.
}

\author{
JAIME URIBE-M.
}

\begin{abstract}
As a result of a redefinition of Frullania subg. Meteoriopsis Spruce and study of the type material, Frullania angulata Mitt. and F. longistipula Steph. are affiliated to Frullania sect. Intumescentes R. M. Schust. Full descriptions and illustrations of the two species are provided.
\end{abstract}

Key words: Hepaticae, Frullania sect. Intumescentes, Frullania subgenus Meteoriopsis

Jaime Uribe-M. Instituto de Ciencias Naturales, Facultad de Ciencias, Universidad Nacional de Colombia. Apartado 7495, Bogotá, D. C. Colombia; e-mail: juribem@unal.edu.co

\section{INTRODUCTION}

Stephani (1911) assigned 60 species of Frullania to F. subg. Meteoriopsis Spruce based solely on possession of a pendant habit, including nine species from Africa. Vanden Berghen (1976) reduced six of them to synonymy of $F$. angulata and transferred F. bullata Steph. (=F. sphaeroflora Steph.) to $F$. subg. Chonanthelia and treated these African species as a separate group within the subgenus Thyopsiella Spruce (as subg. Frullania). Uribe and Gradstein (2003) and Uribe (2008) pointed out that the main diagnostic characters of subg. Meteoriopsis are (i) leaves deeply cordate-auriculate with two large auricles at leaf base, one dorsal and one ventral, and (ii) leaves strongly convoluted and spreading widely when moistened. Accordingly, several species previously assigned to subg. Meteoriopsis were transferred to other subgenera by Uribe (2008). Demaret and Vanden Berghen (1950) treated $F$. angulata and F. longistipula within $F$. subg. Meteoriopsis. Later, Vanden Berghen (1976) treated both species as 'Groupe du F. angulata', and considered F. subg. Meteoriopsis as a synonym of this group. In this paper, F. angulata Mitt. and F. longistipula Steph are affiliated to sect. Intumescentes R. M. Schust. as defined by Hentschel et al. (2009), and character- ized by lobules long-cylindrical to clavate, stylus filiform (Schuster 1985), leaves convoluted around the stem when dry, obliquely spreading when wet. As Hentschel et al. (2009) pointed out, 'The presence of the African $F$. angulata Mitt. within $F$. sect. Obtusilobae seems somewhat anomalous because this species matches the morphology of $F$. sect. Intumescentes rather than of $F$. sect. Obtusilobae.'

\section{RESULTS}

Frullania angulata Mitt.

Figs $1 \& 2 \mathrm{~A}, \mathrm{~B}$

J. Proc. Linn. Soc. [London], Bot. 7: 169. 1864.

TyPe: CAMEROON, Mt. Cameroon, Jan 1862, Mann s.n. (HOLOTYPE, NY!).

Plants of medium to large size, up to $18 \mathrm{~cm}$ long and $1.5 \mathrm{~mm}$ wide including leaves, dark reddish to black, irregularly pinnate. Branches frequent, Frullania-type, to $1 \mathrm{~cm}$ long. Stems 275 $300 \mu \mathrm{m}$ wide in cross section. Leaf-lobes slightly imbricate, slightly convoluted around the stem when dry, spreading when wet, ovate, rounded, symmetrical, concave, 600-1675 × 520-1175 $\mu \mathrm{m}$, apex acute to apiculate, margin entire, dorsal base auriculate, arching over the stem, ventral base not 
auriculate. Leaf-lobe cells: apical cells 10-15 $\times$ 5-7 $\mu \mathrm{m}$, median cells $12-15 \times 7-10 \mu \mathrm{m}$, basal cells $17-20 \times 7-10 \mu \mathrm{m}$, walls thick, sinuous, with trigones inconspicuous and intermediate thickenings. Lobules cylindrical to long-cylindrical to clavate, contiguous and parallel to the stem, 160-180 $\times 70-80 \mu \mathrm{m}$, sometimes lobules canaliculate to lanceolate. Stylus filiform, three cells long, with a terminal slime papilla. Underleaves subcuadrate, oblong to obovate, contiguous to distant, $1200 \times$ $700-725 \mu \mathrm{m}$, up to $2 \times$ wider than stem, margin entire, undulate, recurved, bifid to $1 / 4$ of their length, segments acute or blunt, base auriculate, auricles rather long, to $200 \mu \mathrm{m}$, undulate, insertion line straight. Branch appendages: first branch underleaf divided to the base into two triangular, entire ventral and dorsal segments. Androecia lateral on short branches, capitate, $1 \mathrm{~mm}$ long, bracts in 4-6 series. Gynoecia terminal on stem, the bracts and bracteoles in three series, bracts bifid, margins entire. Perianth 1/2 exserted, oblong-elliptic, ca $1.5 \mathrm{~mm}$ long, 3-keeled, with a short beak.

DistRIBUTION. Widespread in Tropical Africa (Wigginton 2009).

Frullania angulata Mitt. was erroneously included in F. subg. Meteoriopsis by Stephani (1911). Vanden Berghen's (1976) treatment of $F$. subg. Meteoriopsis as a group of $F$. subg. Thyopsiella was correct based on the two African species of the group treated. My study of the type specimen of $F$. angulata revealed, however, that this species has an acute to apiculate, not rounded leaf-lobe apex (Fig. 1C). This species is apparently a member of $F$. subg. Intumescentes. (Hentschel et al. 2009) along with F. brasiliensis Raddi, F. atrata (Sw.) Nees and F. intumescens (Lehm. \& Lindenb.) Lehm. \& Lindenb.

Frullania angulata can be recognized by its ovate, acute to apiculate stem leaf-lobes and auriculate underleaves, with undulate auricles. This species is related to $F$. serrata Gottsche but in the latter the underleaves are 3-4 times the stem width and have no or very short auricles. Vanden Berghen (1976) also described a new variety, $F$. angulata var. laciniata Vanden Berghen, which is accepted here. The variety is characterized by its female bracts and bracteoles being dentate and laciniate (Fig. 2C).

SPECIMENS EXAMINED: TANZANIA: Southern highland in Mbeya Region, E slope of caldera rim of Rungwe volcano, 2500-2600 m alt. 21 Jan. 1972, Pócs 6504/L (EGR, COL); Mt. Rungwe, N of Tukuyu, 2500-2600 m alt. 17 Sept. 1972, Pócs \& Swai 6767/A (EGR, COL); Kiboriani Mts. $1800 \mathrm{~m}$ alt. 11 March 1972, Pócs \& Mezosi 6566/L (EGR, COL); Kilimanjaro, between Umbve and Lonzo rivers, 1900-2000 m alt. 30 Dec. 1970, Pócs \& Jones 6352/AL (EGR, COL); Morogoro region: Mt. Kanga N of Turiani, 1200-1300 m alt. 27 Feb. 1970, Pócs 6138/L (EGR, COL). ZAÏRE: Nioka, Ituri, $1700 \mathrm{~m}$ alt. 30 March 1978, Lisowski 50803 (EGR, COL).

\section{Frullania angulata var. laciniata Vanden} Berghen

Fig. 2C

Bull. Jard. Bot. Nat. Belg. 46: 72. 1976.

TYPE: MADAGASCAR, sine loco, Forsyth Mayor 526 (HOLOTYPE, G!).

Frullania angulata var. laciniata differs from F. angulata var. angulata only by female bracts and bracteoles with the margin dentate-laciniate (Vanden Berghen 1976).

DiSTRIBUTION. Madagascar.

Frullania longistipula Steph.

Fig. 2 D-I

in Renauld \& Cardot, Bull. Soc. Roy. Bot. Belg. 30: 199. 1891.

TYPE: MADAGASCAR, Camboué 162 (HOLOTYPE, G!).

Plants of medium to large size, $8-15 \mathrm{~cm}$ long, $1.3 \mathrm{~mm}$ wide including leaves, reddish to dark reddish, pendent growth (not projecting). Stems 150-190 $\mu \mathrm{m}$ wide in cross section. Branches frequent, Frullania-type, large, to $6 \mathrm{~cm}$ long. Leaflobes distant to subimbricate, convoluted around the stem when dry, obliquely spreading when wet, ovate, symmetric, plane, 700-980 × 800-1100 $\mu \mathrm{m}$, apex rounded, margin entire, dorsal base auriculate, ventral base not truncate. Leaf cells: apical cells $7-10 \times 7-14 \mu \mathrm{m}$, median cells $10-15$ $\times 12-20 \mu \mathrm{m}$, and basal cells $20-25 \times 24-35 \mu \mathrm{m}$; cells with walls thick, sinuous, with cordate trigones and without intermediate thickenings. Lobules 

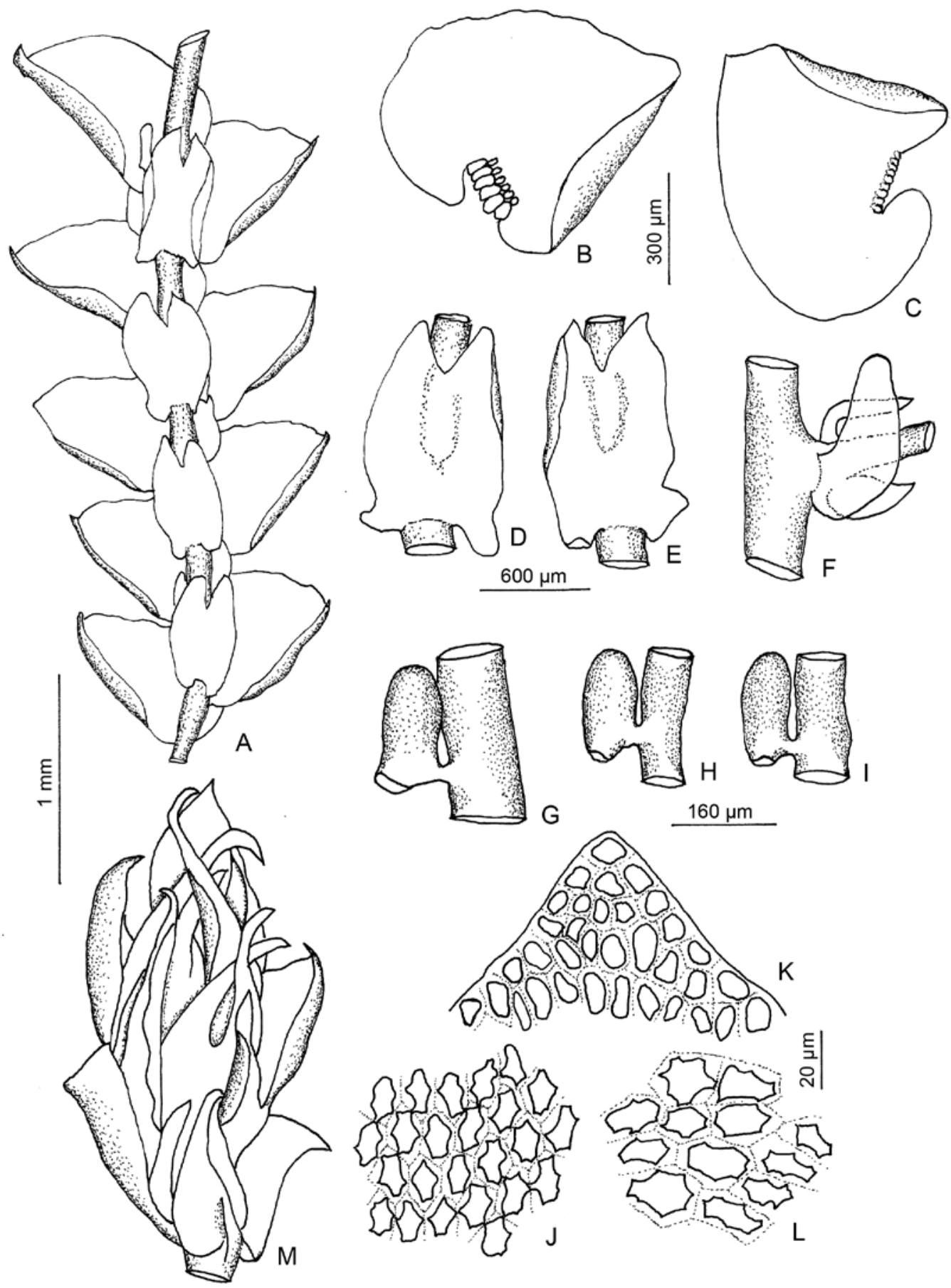

\section{G $160 \mu \mathrm{m}$}
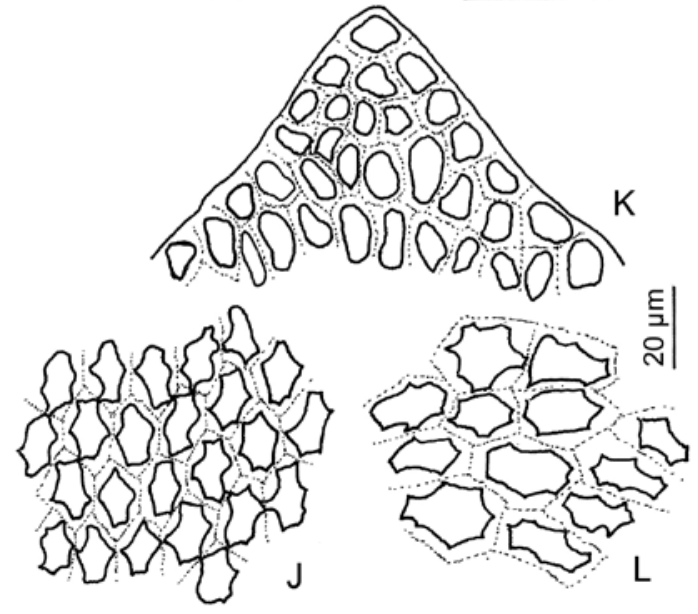

Fig. 1. Frullania angulata Mitt. A - part of shoot, ventral view, B \& C - stem leaves, D \& E - underleaves, F - first branch underleaf and first branch leaf, G-I - lobules, J - median leaf cells, K - apical leaf cells, L - basal leaf cells, M - gynoecial bracts and bracteoles (all from type of F. angulata). 

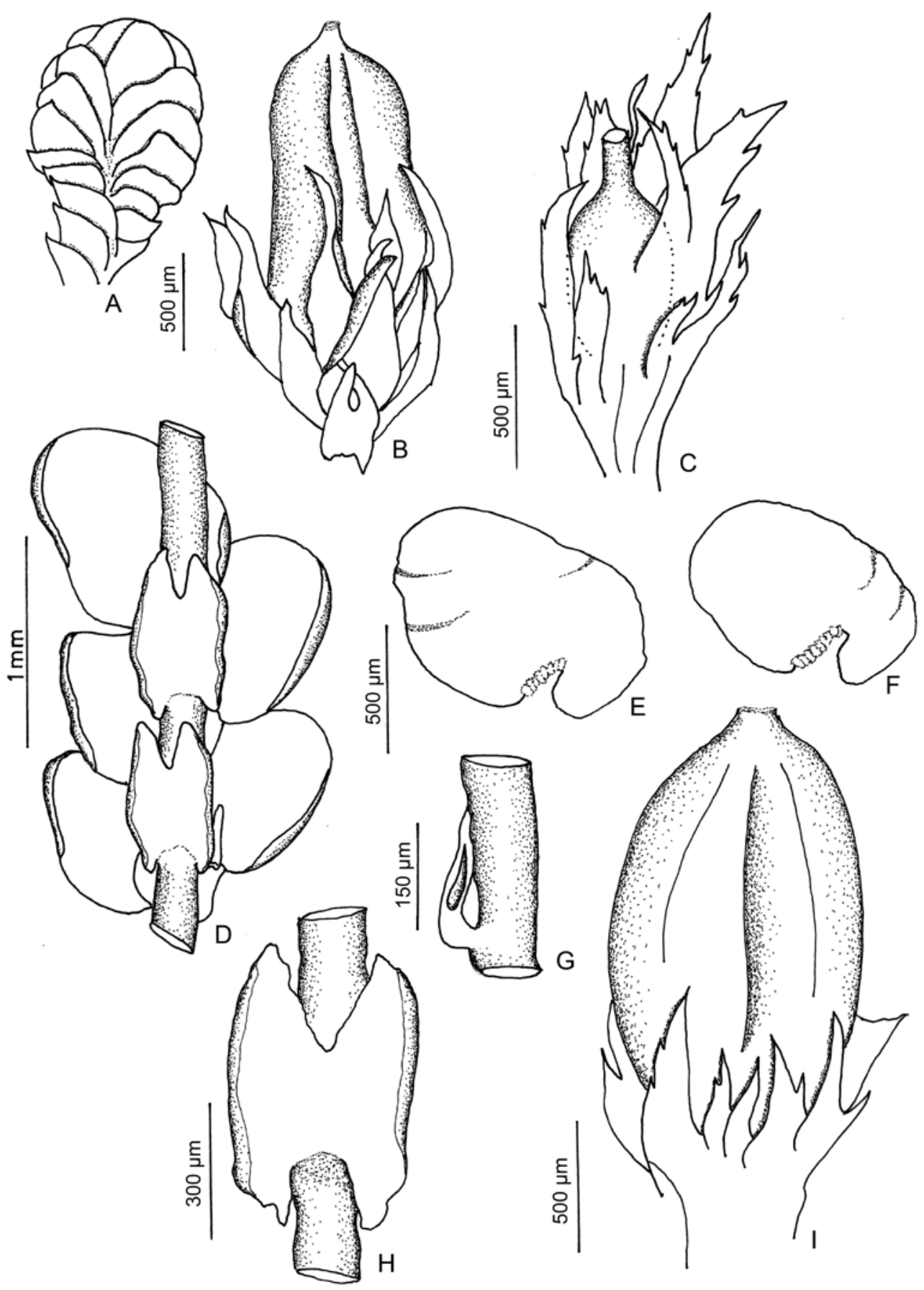

Fig. 2. Frullania angulata Mitt. A - androecium, B - perianth; F. angulata var. laciniata Vanden Berghen. C - perianth with laciniate bracts and bracteole. D-I - F. longistipula Steph. D - part of shoot, ventral view, E \& F - stem leaves, G - lobules, canaliculate, $\mathrm{H}$ - underleaves, I - perianth (A \& B from type of $F$. angulata; C from type of $F$. angulata var. laciniata; D modified from Vanden Berghen (1976); E-I from the type of F. longistipula). 
clavate, sometimes explanate or laminate, 200$230 \mu \mathrm{m}$, parallel and contiguous to stem. Stylus 3-4 cells, to $60 \mu \mathrm{m}$ long. Underleaves ovate to subquadrate, distant, to $275-510 \times 420-600 \mu \mathrm{m}$, up to 3 times wider than stem, margin entire, bifid to $1 / 3$ of their length, segments acute, base with auricles, insertion line slightly curved. Androecia not seen. Gynoecia on short lateral branches, bracts and bracteoles in 2-3 series, acute, margins entire. Perianth oblong, $750 \mu \mathrm{m}$ long and to $1.5 \mathrm{~mm}$ wide, 5-keeled, smooth, narrowed to a short beak.

\section{DISTRIBUTION. Madagascar.}

Frullania longistipula is a poorly known species. The presence of canaliculate lobules, an important character for placement in a particular subgenus, renders identification difficult. F. longistipula can be recognized by its ovate leaves with a rounded apex and auriculate underleaves, leaf cells without intermediate thickenings walls, and trigones not nodulose. This species is close to $F$. angulata but in the former the leaf apex is acute to apiculate.

ACKNOWLEDGEMENTS. This paper is dedicated to Dr. Tamás Pócs on the occasion of his $80^{\text {th }}$ birthday. Dr. Pócs gave me several specimens of African Frullania from his excellent collections for my studies. I thank the National University of Colombia for granting me a leave of absence, the Deutsche Akademischer Austausdienst (DAAD) for a scholarship to work during the first half of 2002 in the Department of Systematic Botany of the University of Göttingen, the curators of herbaria $G$ and
NY for the loan of the type specimens, Dr. Robbert Gradstein (Paris) for helpful comments on the manuscript, and Jörn Hentschel (Jena) for comments about subgeneric classification of the genus Frullania.

\section{REFERENCES}

Demaret F. \& VAnden Berghen C. 1950. Révision des espèces africaines du genre Frullania Raddi, sous-genre Meteoriopsis Spruce. Bull. Jard. Bot. État Bruxelles 20: $1-10$.

Hentschel J., von Konrat M. J., Pócs T., SchäFER-VerWimp A., SHAW A. J., SCHNEIDER H. \& HEINRICHS J. 2009. Molecular insights into the phylogeny and subgeneric classification of Frullania Raddi (Frullaniaceae, Porellales). Molec. Phylogenet. Evol. 52: 142-156.

StePhANi F. 1911. Species Hepaticarum. 4. Acrogynae (pars tertia). Georg \& Cie., Geneva, Basel.

SCHUSTER R. M. 1985. Studies on Porellinae: New taxa of Jubulaceae. Phytologia 57: 369-373.

Uribe-M. J. 2008. Monografía de Frullania subgénero Meteoriopsis (Frullaniaceae, Marchantiophyta). Caldasia 30: 49-94.

URIBE-M. J. \& GRAdSTEIN S. R. 2003. Type studies on Frullania subgenus Meteoriopsis (Hepaticae). I. The lectotypification of the genus Frullania, F. subgen. Thyopsiella and $F$. subgen. Meteoriopsis, and some species transferred from subgen. Meteoriopsis to subgen. Thyopsiella. Cryptog. Bryol. 24: 193-207.

VANDEn Berghen C. 1976. Frullaniaceae (Hepaticae) Africanae. Bull. Jard. Bot. Natl. Belg. 46: 1-220.

WigGinTON M. J. 2009. Checklist and distribution of the liverworts and hornworts of sub-Saharan Africa, including the East African Islands. Tropical Bryology Research Reports 8: $1-116$. 